\title{
Using geochemical and isotopic chemistry to evaluate glacier melt contributions to the Chamkar Chhu (river), Bhutan
}

\author{
Mark W. WILLIAMS, ${ }^{1,2}$ Alana WILSON, ${ }^{1,2}$ Dendup TSHERING, ${ }^{3}$ Pankaj THAPA, ${ }^{3}$ \\ Rijan B. KAYASTHA ${ }^{4}$ \\ ${ }^{1}$ Institute of Arctic and Alpine Research, University of Colorado at Boulder, Boulder, CO, USA \\ ${ }^{2}$ Department of Geography, University of Colorado at Boulder, Boulder, CO, USA \\ ${ }^{3}$ Center for Climate Change and Spatial Information, Royal University of Bhutan, Sherubtse College, Kanglung, Bhutan \\ ${ }^{4}$ Department of Environmental Science and Engineering, School of Science, Kathmandu University, Kathmandu, Nepal \\ Correspondence: Mark W. Williams <markw@snobear.colorado.edu>
}

\begin{abstract}
Water stored as ice and snow at high elevations is a resource that plays an important role in the hydrologic cycle, particularly in the timing and volume of downstream discharge. Here we use geochemical and isotopic values of water samples to evaluate relative contributions of melting glacier ice and groundwater to discharge in Bhutan. River water samples were collected between 3100 and $4500 \mathrm{~m}$ in the Chamkar Chhu (river) watershed of central Bhutan's Himalaya. Glacier ice and snow were sampled in the ablation zone of Thanagang glacier. Groundwater was parameterized from spring water at elevations of 3100 and $3600 \mathrm{~m}$. Synoptic sampling was carried out in separate expeditions in July, August and late September 2014, to characterize monsoon and post-monsoon conditions. Results from a two-component hydrologic mixing model using isotopic and geochemical (sulphate) values show that the glacier outflow contributions decrease from $\sim 76 \%$ at $4500 \mathrm{~m}$ to $31 \%$ at $3100 \mathrm{~m}$. A fourcomponent hydrologic mixing model using end-member mixing analysis shows glacier ice melt increasing as a proportion of discharge over the 3 month sampling period, and consistently decreasing with distance downstream of Thanagang glacier terminus. These results indicate that isotopic and geochemical tracers can provide a quantitative evaluation of the source water contributions to streamflow in Bhutan.
\end{abstract}

KEYWORDS: glacier discharge, glacier hydrochemistry, meltwater chemistry, mountain glaciers

\section{INTRODUCTION}

Bhutan is a country that is already at risk from a changing global climate (Meenawat and Sovacool, 2011). Almost 70\% of the population in Bhutan is directly or indirectly dependent on subsistence agriculture that is fed mostly by rivers originating from the glaciers and snow of the eastern Himalaya and by the abundance of monsoonal rainfall. Agriculture and hydroelectricity are two of the most prominent economic activities of the country. Bhutan, a small and poorly developed country in the Himalaya, faces numerous vulnerabilities related to climate change, including landslides and flooding from melting glaciers, and impaired hydroelectricity generation (Meenawat and Sovacool, 2011).

Bhutan lies in the eastern Himalaya, extending from $26^{\circ} 40^{\prime}-28^{\circ} 15^{\prime} \mathrm{N}$ to $88^{\circ} 45^{\prime}-92^{\circ} 10^{\prime} \mathrm{E}$ and covering an area of $38394 \mathrm{~km}^{2}$. The relief extends from $\sim 150 \mathrm{~m}$ in the south to $>7000 \mathrm{~m}$ in the north, making it highly diverse in climate and vegetation characteristics. Bhutan is home to about 983 glaciers and about 2800 glacial lakes, a handful of which are at risk of catastrophic flooding (Nayar, 2009). The total area under snow/glaciers at maximum snow accumulation is $2989 \mathrm{~km}^{2}(7.5 \%$ of the total country area).

Bhutan's glaciers are at risk because of present and future changes in climate. Naito and others (2012) surveyed surface lowering of glacier ablation zones from 2002 to 2004 in the northern region of Bhutan and estimated lowering rates of $0-3 \mathrm{~m} \mathrm{a}^{-1}$ for debris-covered glaciers and $\sim 5 \mathrm{~m} \mathrm{a}^{-1}$ on the ablation areas of clean glaciers. Karma and others (2003) reported that the average annual terminal retreat of glaciers in Bhutan is higher than in Nepal. They suggested that this is because glacier mass balances vary more in places with higher precipitation and higher temperatures, such as Bhutan. Rupper and others (2012) conducted a modelling study of Bhutan and estimated that under the conservative scenario of an additional $1{ }^{\circ} \mathrm{C}$ regional warming, glacier retreat will continue until about $25 \%$ of Bhutan's glacierized area disappears and the annual meltwater flux, after an initial spike, drops by as much as $65 \%$. Kääb and others (2012) estimated a mass balance for Bhutan glaciers of $-0.52 \pm 0.16 \mathrm{~m}$ for 2003-08 using a geodetic method, while for 1999-2010, Gardelle and others (2013) estimated a smaller mass-balance loss of $-0.22 \pm 0.12 \mathrm{~m}$ using Shuttle Radar Topography Mission (SRTM) and Satellite Pour l'Observation de la Terre (SPOT) data for their geodetic approach.

Almost all the rivers of Bhutan originate from the glaciers/ snow-clad mountains of the eastern Himalaya, and $>50 \%$ of its 20 districts are characterized by the presence of glaciers and/or snow cover. There are growing concerns about streams and water sources drying up as a result of the negative mass balance of glaciers and irregular and erratic monsoons. There are also opposing views about the impact on the economy of the country of climate change that may result from glaciers melting. Scientific study of hydrological and other models, including research on climate change impacts, is lacking mainly because of the scarcity of data and research capabilities in this region (Land Use Planning Project Bhutan, 1997; Bajracharya and others, 2007).

A better understanding of the contribution of melting glacial ice to stream discharge in Bhutan is necessary to 


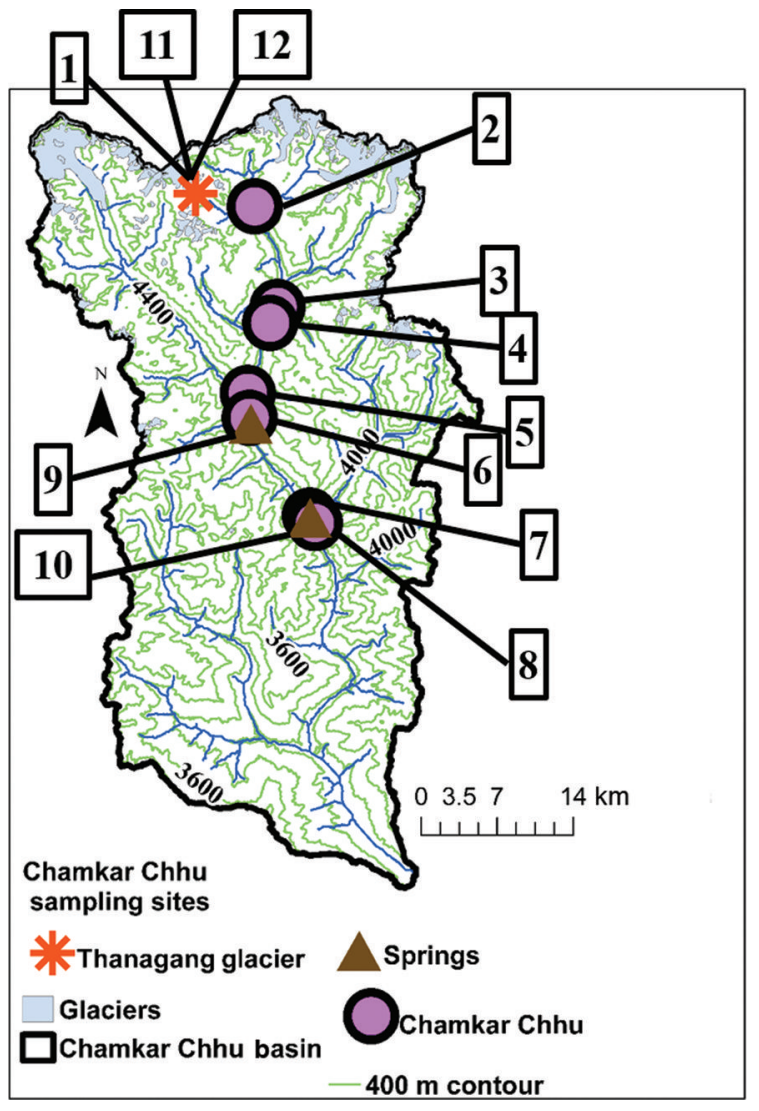

Fig. 1. Location and site map for the Chamkar Chhu (river), Bhutan. Sampling sites are shown for river, springs, glacial outflow, ice and snow. Site location code numbers are defined in Table 1.

understand how future changes in the ice may impact water security. However, quantifying the contribution of melting glacier ice is challenging because the physical processes involved in glacier ablation and watershed hydrology are complex, resulting in large uncertainties (La Frenierre and Mark, 2014). Traditional approaches to estimating glacial ablation, such as the glaciological and hydrological mass-balance methods, are particularly difficult to conduct in remote areas such as Bhutan where there is little infrastructure to support field studies. Hydrological modelling represents the most frequently applied approach to quantifying the proportional contribution of glacial meltwater to streamflow. Schaner and others (2012) used the Variable Infiltration Capacity (VIC) energy-balance hydrologic model to estimate glacial contributions to surface flows at the global scale and at a spatial resolution of $0.25^{\circ}$ and reported that $>90 \%$ of the population at risk from changes in glacial melt live in Asia. Lutz and others (2014) used a fully distributed high-resolution cryospheric hydrological model and projected an increase in runoff for the Brahmaputra drainage at least until 2050, caused primarily by an increase in precipitation.

An alternative modelling approach is the hydrochemical tracer method, which is based on the idea that waters of different provenance tend to have distinctive hydrochemical signatures as a result of the hydrological, geological and biological processes in which they have participated (Drever, 1997). A major advantage of this approach is that tracer analyses do not require the detailed and often longterm glaciological and meteorological observations required for the other approaches, since one synoptic sampling suite is sufficient to provide a reasonable snapshot of the watershed
(La Frenierre and Mark, 2014). While the hydrochemical tracer approach has been used widely in seasonally snowcovered catchments in the USA and Europe, it has seldom been used in glacierized catchments of the Hindu KushHimalayan complex (Klaus and McDonnell, 2013).

Here we conduct the first synoptic measurements of stable isotopes of water and geochemical tracers in Bhutan to estimate the relative contributions of glacier outflow to river discharge during the monsoonal and post-monsoonal periods. Racoviteanu and others (2013) have shown that isotopic tracers collected in the Langtang valley of central Nepal are helpful in understanding the glacier outflow contributions to streamflow. Our primary objective here is to evaluate isotopic and geochemical tracers and use them to parameterize two- and multicomponent hydrologic mixing models in order to understand the contribution of glacial outflow to the Chamkar Chhu (river) in central Bhutan. This allows for quantification of the contribution of glacier outflow to river discharge along an elevational gradient and over the course of a 3 month window transitioning from the monsoon to post-monsoon season.

\section{SITE DESCRIPTION}

This study was conducted in the Chamkar Chhu basin in the Bumthang district located in north-central Bhutan (Fig. 1). The altitude of the study area varies from $2600 \mathrm{~m}$ in the south to $>6000 \mathrm{~m}$ on the border with Tibet. Most of the northern area of the Chamkar Chhu basin is covered by glaciers and snow, covering almost $35 \%$ of the basin at maximum snow cover (Land Use Planning Project Bhutan, 1997). The extent of snow and ice is more than twice that found in any other catchment in Bhutan, making it one of the most important rivers in Bhutan for understanding the role of snow and ice melt in river flow (Land Use Planning Project Bhutan, 1997).

The Chamkar Chhu flows predominantly north to south, with several minor tributaries but no large ones. It is also referred to as the Bumthang river on some maps. At the headwaters of the river at $5500 \mathrm{~m}$ is the outflow of Thanagang glacier (Table 1). River samples were collected along an elevational transect from $4500 \mathrm{~m}$ at Churugang to $3173 \mathrm{~m}$ at Riphug; where tributaries flowed into the main stem of the river, water samples were collected above and below the intersection. Two springs were sampled to represent groundwater. Ice and snow were also sampled near the outlet of Thanagang glacier, as was the glacier outflow. Samples were collected during expeditions in July (highest monsoon intensity), August (declining monsoon) and September (post-monsoon).

\section{METHODS}

Three field campaigns were conducted to collect water chemistry samples in order to analyze a full suite of isotopic and geochemical data from the Chamkar Chhu and its potential source waters. The hydrochemical data allow for various approaches to hydrograph separation in order to estimate the composition of the Chamkhar Chhu in the monsoon and post-monsoon seasons of 2014.

\section{Watershed methods}

Protocols for sample collection followed those developed by the Niwot Ridge Long-Term Ecological Program (NWT 
Table 1. Sampling locations, site codes, elevation, chemical content of samples and $\delta^{18} \mathrm{O}$ values of samples for the July and September 2014 expeditions

\begin{tabular}{|c|c|c|c|c|c|c|c|c|c|c|c|}
\hline \multirow[t]{2}{*}{ Location } & \multirow[t]{2}{*}{ Type } & \multirow{2}{*}{$\begin{array}{l}\text { Elevation } \\
\text { m }\end{array}$} & \multirow[t]{2}{*}{ Code } & \multicolumn{4}{|c|}{ July } & \multicolumn{4}{|c|}{ Sept } \\
\hline & & & & $\begin{array}{c}\mathrm{Ca}^{2+} \\
\mu e q \mathrm{~L}^{-1}\end{array}$ & $\begin{array}{c}\mathrm{K}^{+} \\
\mu e q \mathrm{~L}^{-1}\end{array}$ & $\begin{array}{c}\mathrm{SO}_{4}{ }^{2-} \\
\mu e \mathrm{~L}^{-1}\end{array}$ & $\begin{array}{c}\delta^{18} \mathrm{O} \\
\% o\end{array}$ & $\begin{array}{c}\mathrm{Ca}^{2+} \\
\mu e q L^{-1}\end{array}$ & $\begin{array}{c}\mathrm{K}^{+} \\
\mu e q \mathrm{~L}^{-1}\end{array}$ & $\begin{array}{c}\mathrm{SO}_{4}{ }^{2-} \\
\mu \mathrm{eq} \mathrm{L}^{-1}\end{array}$ & $\begin{array}{c}\delta^{18} \mathrm{O} \\
\% \text { o }\end{array}$ \\
\hline Thana outflow & glacier & 5147 & 1 & 28.78 & 0.46 & 4.23 & -15.27 & 54.61 & 0.67 & 4.16 & -16.45 \\
\hline Churugang & river & 4556 & 2 & 102.08 & 1.15 & 8.37 & -14.2 & 139.94 & 1.08 & 9.24 & -15.71 \\
\hline Yarphu downstream & river & 4008 & 4 & 151.29 & 1.86 & 19.7 & -14.14 & 198.20 & 6.54 & 24.8 & -15.23 \\
\hline Tsampa upstream & river & 3713 & 5 & 160.55 & 3.18 & 32.73 & -13.98 & 205.62 & 3.25 & 37.77 & -14.97 \\
\hline Tsampa downstream & river & 3641 & 6 & 258.69 & 3.86 & 42.16 & -13.63 & 320.52 & 3.93 & 49.91 & -14.66 \\
\hline Riphug upstream & river & 3188 & 7 & 246.23 & 7.03 & 45.35 & -13.4 & 304.38 & 6.22 & 51.11 & -14.47 \\
\hline Riphug downstream & river & 3173 & 8 & 237.21 & 5.49 & 47.3 & -13.22 & 288.57 & 10.45 & 54.13 & -14.34 \\
\hline Spring at Tsampawog & deep groundwater & 3624 & 9 & 145.05 & 20.77 & 80.09 & -12.89 & 162.04 & 28.15 & 84.20 & -13.37 \\
\hline Spring at Riphug & shallow groundwater & 3148 & 10 & 43.16 & 2.37 & 24.71 & -11.39 & 45.51 & 2.37 & 23.65 & -13.11 \\
\hline Thana ice 1 & ice & 5154 & 11 & 4.02 & 0.60 & 4.5 & -16.74 & - & - & - & - \\
\hline Snow & snow & 5150 & 12 & 7.15 & 0.26 & 4.31 & -18.12 & - & - & - & - \\
\hline
\end{tabular}

LTER) for water and precipitation in high-elevation alpine areas (Williams and others, 2006, 2009). Water samples were collected in polyethylene bottles soaked overnight with deionized water and then rinsed copiously five times; bottles were further rinsed three times with sample water at the time of collection. All samples were filtered in the field within 24 hours of collection using $47 \mathrm{~mm}$ glass fibre filters with an effective pore size of $1.0 \mu \mathrm{m}$. Snow and ice samples were allowed to melt at ambient temperature and were filtered within 24 hours of melt. Water for isotopic analyses was stored in $25 \mathrm{~mL}$ glass vials with no headspace and sealed with taperseal caps to prevent diffusion and resulting fractionation. Samples were kept chilled until shipped back to Boulder, CO, USA, for analysis.

\section{Laboratory methods}

All surface water, snow, ice and spring samples were analyzed for $\mathrm{pH}$, specific conductance, acid-neutralizing capacity, $\mathrm{H}^{+}, \mathrm{NH}_{4}{ }^{+}, \mathrm{Ca}^{2+}, \mathrm{Na}^{+}, \mathrm{Mg}^{2+}, \mathrm{K}^{+}, \mathrm{Cl}^{-}, \mathrm{NO}_{3}{ }^{-}, \mathrm{SO}_{4}{ }^{2-}$, $\mathrm{Si}$, dissolved organic carbon, dissolved organic nitrogen and $\delta^{18} \mathrm{O}$. Samples for chemical and nutrient content were analyzed at the Kiowa wet chemistry laboratory run by the NWT LTER, Boulder, CO, USA, following the protocols of Williams and others (2009). Detection limits for all solutes were $<1 \mu \mathrm{eq} \mathrm{L}{ }^{-1}$ (see Williams and others, 2009, for values). Here we present a limited number of cation and anion values, along with stable isotopic values for water.

Isotopic analysis was conducted using a Picarro wavelength-scanned cavity ringdown spectrometer. The ${ }^{18} \mathrm{O}$ values are expressed in conventional delta $(\delta)$ notation in units of per mil (\%) relative to Vienna Standard Mean Ocean Water (VSMOW) with a precision of $\pm 0.05 \%$ :

$$
\delta^{18} \mathrm{O}=\frac{\left({ }^{18} \mathrm{O} /{ }^{16} \mathrm{O}\right)_{\text {sample }}-\left({ }^{18} \mathrm{O} /{ }^{16} \mathrm{O}\right)_{\text {vsMOW }}}{\left({ }^{18} \mathrm{O} /{ }^{16} \mathrm{O}\right)_{\text {VSMOW }}} \times 1000
$$

Deuterium ratios $(\delta \mathrm{D})$ were calculated in the same manner.

\section{Hydrograph separation models}

\section{Two-component mixing models}

Bivariate mixing diagrams allow for consideration of multiple paired measurements of two tracers in order to separate a hydrograph between two components. These biplots were used by Williams and others (2009) to define snowmelt and base flow as end members in a two-component hydrograph mixing model for a seasonally snow-covered catchment in the Rocky Mountains, USA. Klaus and McDonnel (2013) note that the bivariate plots in Williams and others (2009) are a data-based approach to end-member selection and thus a less ad hoc way to identify end members compared with an a priori approach in which end-members are preassigned.

A simple two-component hydrograph separation was also conducted. The glacier outflow (go) and groundwater (gw) water components of streamflow can be estimated using $\delta^{18} \mathrm{O}$ (e.g. Sklash and others, 1976; Hooper and Shoemaker, 1986):

$$
Q_{\text {stream }} \times C_{\text {stream }}=Q_{\text {go }} \times C_{\text {go }}+Q_{\text {gw }} \times C_{\text {gw }}
$$

with the water balance constraint that

$$
Q_{\text {stream }}=Q_{\text {go }}+Q_{\mathrm{gw}}
$$

where $Q$ is volume flow rate, $C$ is $\delta^{18} \mathrm{O}$ or the value of some other tracer, and the subscripts describe the water source. Glacier outflow water is generally composed of ice melt and snowmelt, with the potential for inclusion of some rainwater during the monsoon. Several conditions must be met by this two-component model, including (e.g. Suecker and others, 2000): (1) tracer values of each component must be significantly different; (2) there are only two components contributing to streamflow; and (3) the tracer composition of each component is constant for the duration of the event, or variation is known from measurements. By combining Eqns (2) and (3), the following equation is written:

$$
Q_{\mathrm{go}}=Q_{\text {stream }}\left[\frac{C_{\text {stream }}-C_{\mathrm{gw}}}{C_{\mathrm{go}}-C_{\mathrm{gw}}}\right]
$$

Note that Eqn (4) allows calculation of the percent contribution of glacier outflow and groundwater to river discharge without the need to measure river discharge. This approach can be extended to more than two end members, with the constraint that the number of independent tracers is one less than the number of end members (e.g. a three-component mixing model requires two independent tracers) (Uhlenbrook and Hoeg, 2003; Liu and others, 2004). 
Equations (2) and (3) were also used to determine reacted and unreacted components by substituting the geochemical tracer sulphate for $\delta^{18} \mathrm{O}$ and unreacted and reacted waters for glacier outflow and groundwater (Suecker and others, 2000; Liu and others, 2004; Williams and others, 2009). Reacted waters have undergone ion exchange and acquired an elevated geochemical solute load; however, their isotopic signature is unaffected by their flow path. They can consist of previously unreacted waters, such as glacier outflow or snowmelt, which are routed through the subsurface, as reported by Wels and others (1991a,b), Uhlenbrook and Hoeg (2003) and Liu and others (2004) for seasonally snow-covered catchments.

\section{Multicomponent mixing models}

A limitation of the mixing model approach described above is the calculation of uncertainty in the hydrograph separations. One method of evaluating uncertainty in hydrograph separations is to use end-member mixing analysis (EMMA). EMMA is a commonly applied method to identify and quantify the dominant runoff-producing sources of water in unmonitored catchments (Barthold and others, 2011). It differs from the two-component mixing model in that it can also identify flow paths and potentially additional sources of water (Liu and others, 2004) by considering a broader suite of geochemical data from each sample. Thus, EMMA results are not directly comparable to the two-component mixing model described above, as demonstrated by Liu and others (2004) for a seasonally snow-covered catchment.

The diagnostic tools of mixing models (Hooper, 2003) were used in combination with tracer-based EMMA (Christophersen and others, 1990; Christophersen and Hooper, 1992) to identify the most important water sources contributing to river water. Conservative tracers and the number of end members that contribute to discharge were identified from chemical and isotopic data of the Chamkar Chhu, not from end-member samples. Note that EMMA differs from the two-component mixing models by: (1) using the approach of Hooper (2003) to identify conservative geochemical and isotopic tracers rather than using a priori assumptions; (2) having more tracers than end members; (3) using principal component analysis (PCA) as discussed below to determine the potential end members rather than using a priori assumptions; (4) using the PCA results to reduce the number of tracers and parameterize the hydrologic mixing models instead of the geochemical and isotopic values; and (5) providing a quantitative assessment of the results.

Conservative tracers were determined by examining the distribution of residuals (the difference between original tracer concentration values and the values when the tracer is projected into the $U$-space, each axis of which is defined by a principal component from the PCA). A random distribution of residuals (considered to be $R^{2}<0.4$ ) indicates that the tracer behavior is predictable and therefore conservative. The number of end members was determined by the number of eigenvectors required to create a $U$-space in which the difference between projected and measured tracer values for each conservative solute/isotope had correlation coefficients with an $R^{2}$ value $\geq 0.85$. Tracer concentrations in end members were standardized (mean = 0 , standard deviation =1) using the mean and standard deviation of streamflow samples and projected using the same eigenvectors. Using the PCA, we take the product of the data matrix and its transpose, which gives us eigenvectors that form the geometrical coordinates of the $U$ space. The sum of the eigenvalues equals the variance in the data and each eigenvalue gives the amount of variance explained by the corresponding end member.

End members were selected based on their Euclidean separation in the $U$-space onto which the streamflow samples are projected. Thus, $U$-space projections are substituted for tracer concentrations in hydrologic mixing models, and proportional contribution to streamflow is calculated as the distance between streamflow samples and each end member. For the purposes of calculating percent contribution, river samples plotting outside the bounding shape were moved to the line connecting the end members using the methodology of Liu and others (2004). The relative contributions of end members to streamflow were expressed as fractions of the total streamflow on each sampling date.

\section{RESULTS AND DISCUSSION}

\section{Water isotopes}

We examined trends in oxygen isotopes with elevation for 32 water samples collected in the Chamkar Chhu basin. We show $\delta^{18} \mathrm{O}$ and some of the geochemical values for the July expedition in Table 1. The $\delta^{18} \mathrm{O}$ values ranged from $-11.39 \%$ at the lowest-elevation spring to $-16.74 \%$ for glacial ice collected near the terminus of Thanagang glacier. Outflow of Thanagang glacier was sampled in July and September, with $\delta^{18} \mathrm{O}$ values of $-15.27 \%$ and $-16.45 \%$, respectively. One snow sample was collected on the glacier surface and had a $\delta^{18} \mathrm{O}$ value of $-18.12 \%$, the most depleted $\delta^{18} \mathrm{O}$ of any sample and about $1.5 \%$ more depleted than the glacier ice. The combined $\delta^{18} \mathrm{O}$ values for river samples display a spread of $\sim 1.5 \%$ from an elevation of about 4500-3100 m, influenced by a changing proportion of source waters with variable $\delta^{18} \mathrm{O}$ values. The distribution of $\delta^{18} \mathrm{O}$ with elevation (Fig. 2) shows decreasing trends in $\delta^{18} \mathrm{O}$ with elevation for river samples for all three expeditions. The rate of decrease in $\delta^{18} \mathrm{O}$ for river samples is $\sim-0.98 \%$ per $1000 \mathrm{~m}$ elevation change, similar to the $-0.6 \%$ per $1000 \mathrm{~m}$ elevation change reported by Racoviteanu and others (2013) for the Langtang basin, Nepal. The correlation between elevation and $\delta^{18} \mathrm{O}$ for river samples is significant at the $95 \%$ confidence interval for all three expeditions ( $R^{2}$ range $\left.0.91-0.98\right)$. It is noteworthy that at all sites the $\delta^{18} \mathrm{O}$ values become progressively more depleted with time (Fig. 2).

We also investigated the relationship between hydrogen and oxygen isotopes $\left(\delta \mathrm{D}-\delta^{18} \mathrm{O}\right)$ (Fig. 3). Generally, $\delta \mathrm{D}$ and $\delta^{18} \mathrm{O}$ in all precipitation events collected globally are related according to $\delta \mathrm{D}=8 \delta^{18} \mathrm{O}+10$, defined as the global meteoric waterline (GMWL) (Craig, 1961). The $\delta \mathrm{D}-\delta^{18} \mathrm{O}$ relationship for all water samples collected in this study plots near the GMWL, yielding a relationship of

$$
\delta \mathrm{D}=7.4 \delta^{18} \mathrm{O}+3.8 \quad\left(R^{2}=0.997 ; n=32\right)
$$

with a standard error in the slope of 0.15 and a standard error of 2.2 in the intercept. These results suggest very little loss of snow and ice to sublimation or evaporation (e.g. Williams and others, 2006) since the equation is close to that for global precipitation. A $y$-intercept lower than the GMWL can be indicative of evapotranspiration processes in the catchment (Murad and Krishnamurthy, 2007). 


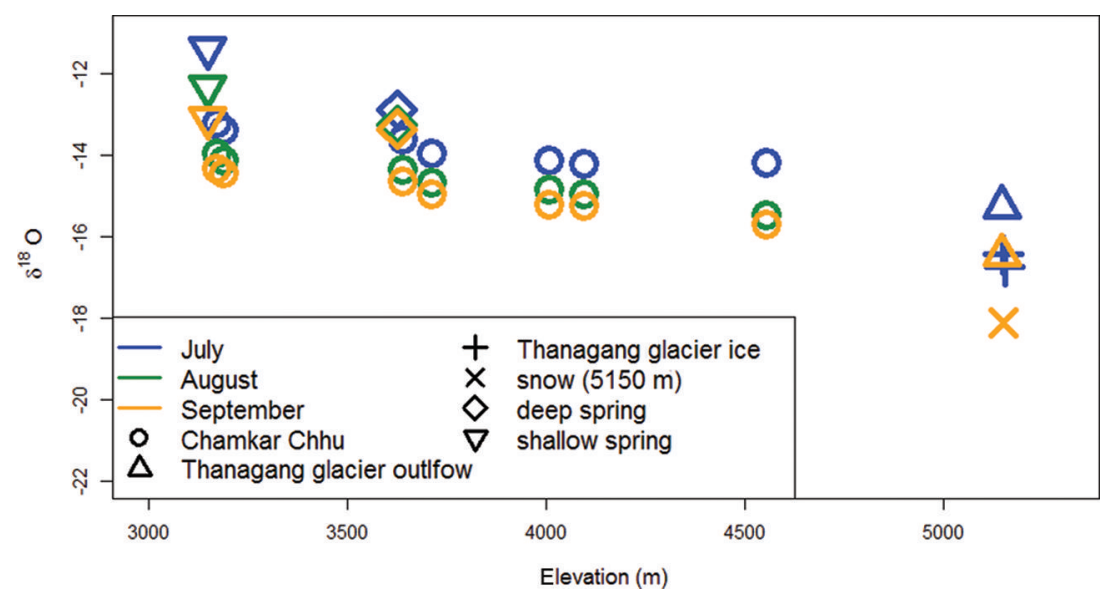

Fig. 2. Values of $\delta^{18} \mathrm{O}$ of water (surface waters, glacier outflow, ice, snow and springs) as a function of elevation. There is a decreasing trend in $\delta^{18} \mathrm{O}$ with elevation.

\section{Solute content}

The solute content of stream waters also changed with elevation in a predictable manner due to mixing of different source waters (Table 1). The lowest concentrations of calcium and sulphate were measured in ice, with concentrations for both solutes $<5 \mu \mathrm{eq} \mathrm{L}^{-1}$. Water from the outflow of Thanagang glacier had concentrations of about $28 \mu \mathrm{eq} \mathrm{L}{ }^{-1}$ for calcium, which is enriched compared with ice, and $4 \mu \mathrm{eq} \mathrm{L}^{-1}$ for sulphate, which is similar to that in snow and ice. As with $\delta^{18} \mathrm{O}$, sulphate in river water was significantly correlated with elevation, increasing by $33 \mu \mathrm{eq} \mathrm{L^{-1 }}$ with a $1000 \mathrm{~m}$ elevation loss ( $R^{2}$ range $\left.0.91-0.92\right)$; calcium concentrations also increased significantly with decreasing elevation, demonstrating that glacier outflow with a relatively low solute load becomes less dominant further downstream.

The higher-elevation groundwater spring at Tsampawog had fairly stable sulphate concentrations that ranged from $80 \mu \mathrm{eq} \mathrm{L}-1$ in July to $84 \mu \mathrm{eq} \mathrm{L}^{-1}$ in September. Calcium concentrations in the Tsampawog spring increased from 145 to $162 \mu \mathrm{eq} \mathrm{L}^{-1}$ between July and September. Potassium values were uniquely enriched in the groundwater samples from Tsampawog, which had concentrations twice as high $\left(>20 \mu \mathrm{eq} \mathrm{L}^{-1}\right)$ as any other sample $\left(<10 \mu \mathrm{eq} \mathrm{L}^{-1}\right)$. At the lower-elevation spring at Riphug, the sulphate concentration was $25 \mu \mathrm{eq} \mathrm{L} \mathrm{L}^{-1}$ in July, $30 \mu \mathrm{eq} \mathrm{L^{-1 }}$ in August and decreased to $24 \mu \mathrm{eq} \mathrm{L}^{-1}$ in September. Calcium concentrations followed the same pattern, with a peak of $49 \mu \mathrm{eq} \mathrm{L}^{-1}$ in August, and values of 43 and $46 \mu \mathrm{eq} \mathrm{L}^{-1}$, respectively, in July and
September. We use 'deep' and 'shallow' to distinguish conveniently between the groundwater at Tsampawog and Riphug, respectively. Other possible explanations for the differences are discussed below.

For both calcium and sulphate concentrations, the July values in the Chamkar Chhu are elevated at the downstream sampling site of each of the three tributaries relative to the corresponding upstream sampling site, with the exception of a slight decline in calcium downstream of Riphug. There is a particularly large increase in sulphate and calcium concentrations below the confluence of the main stem with the right-bank Tsampa tributary, from $161 \mu \mathrm{eqL} \mathrm{L}^{-1}$ sulphate above the confluence to $259 \mu \mathrm{eq} \mathrm{L}^{-1}$ sulphate below the confluence, and calcium values increasing from 161 to $259 \mu \mathrm{eq} \mathrm{L}^{-1}$ (Table 1). In contrast, $\delta^{18} \mathrm{O}$ values remained on the GMWL (Table 1; Fig. 2). These results suggest that inflowing water from the Tsampa tributary is routed through a different lithology from waters in the main stem of the Chamkar Chhu, modifying the chemistry, but that the waters of both the main stem and the Tsampa tributary are isotopically similar.

These solute concentrations are much smaller and with an opposite pattern with elevation compared with the Langtang river. Wilson and others (2016) showed that the outflow of Langtang glacier has calcium and sulphate concentrations of $\sim 400 \mu \mathrm{eq} \mathrm{L}{ }^{-1}$, two orders of magnitude greater than for the Thanagang glacier outflow, suggesting differences in both bedrock geochemistry and glacial environments between the Langtang and Chamkar basins,

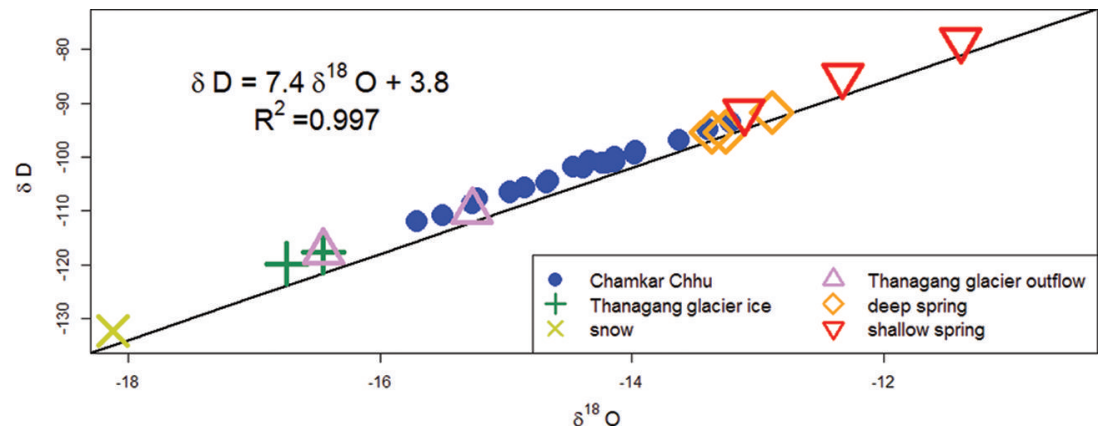

Fig. 3. $\delta^{18} \mathrm{O}$ and $\delta \mathrm{D}$ values for all water samples are highly correlated $\left(R^{2}=0.997 ; n=32\right)$. Isotopic compositions of the water closely follow the GMWL. 


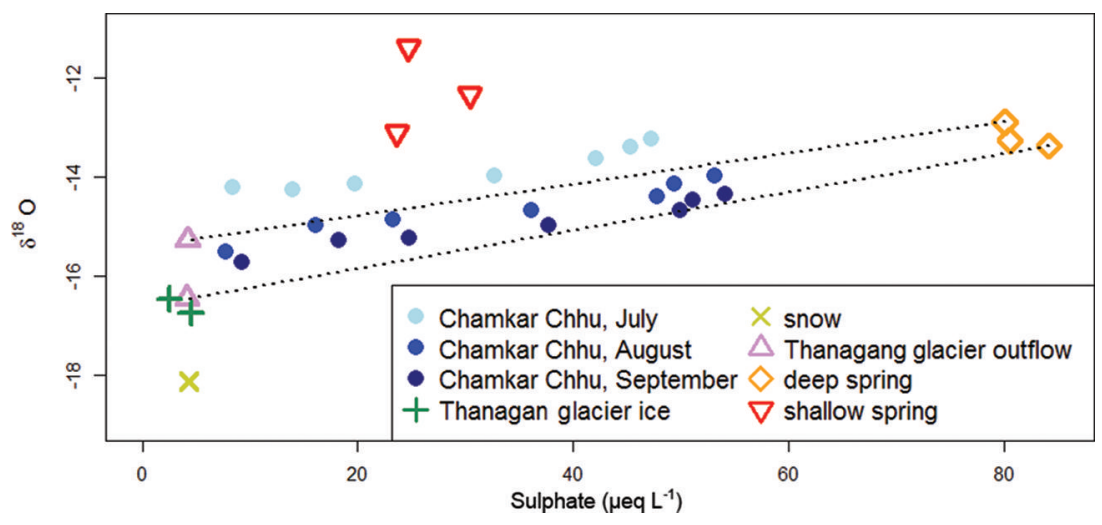

Fig. 4. A binary plot of $\delta^{18} \mathrm{O}$ and sulphate for surface waters from the Chamkar Chhu in 2014, along with potential end members (ice, snow, glacier outflow, springs). Upper dashed line connects Thanagang glacier outflow in July with deep groundwater in July. Lower dashed line connects September samples from the same two locations.

which are controlled largely by the presence of clean ice versus debris-covered ice. In contrast to the Chamkar Chhu, geochemical concentrations for the Langtang river decreased with decreasing elevation (Wilson and others, 2016). These differences in geochemical behaviour of surface waters may be driven in part by the fact that Langtang glacier is debris-covered, while Thanagang is a 'clean' glacier.

\section{Two-component mixing models}

In an effort to understand source waters that might contribute to flow in the river, we plotted $\delta^{18} \mathrm{O}$ versus sulphate of stream waters along with potential end members (Fig. 4). The binary plot of $\delta^{18} \mathrm{O}$ versus sulphate shows that stream waters generally plot on a mixing line between the spring values ('groundwater') and the outflow of Thanagang glacier ('glacier outflow'). However, in general the $\delta^{18} \mathrm{O}$ values for river water tend to plot slightly enriched with respect to the mixing lines, suggesting a possible role for a third end member enriched in $\delta^{18} \mathrm{O}$ with respect to the outflow of the glacier. Such a third end member could be monsoonal rain, which is expected to be enriched in $\delta^{18} \mathrm{O}$ relative to glacier ice due to the warmer temperature of its deposition. However because the isotopic and geochemical values fall close to the mixing line in Figure 4, two sources of water are sufficient to explain the general composition of stream water (Williams and others, 2009). The expedition team was not able to access Thanagang glacier in August, so we were unable to run the mixing model for that expedition.

Based on the binary diagram, two different two-component mixing models were used to characterize 'unreacted' and 'reacted' stream water, and 'groundwater' and 'glacier outflow' stream water (Fig. 5a and b). The two-component hydrograph separations followed the procedure of Suecker and others (2000) and Liu and others (2004), where we used the outflow of Thanagang glacier as one end member and the deep spring groundwater as the other. The mixing model using sulphate as a tracer indicates that, on average, reacted water provided $\sim 35 \%$ of the water in the Chamkar Chhu and unreacted water contributed $\sim 65 \%$, based on the six sampling points at which proportions were quantified. The contribution of reacted water to streamflow increased with decreasing elevation, from only $\sim 5 \%$ at the highestelevation site to $\sim 60 \%$ at the lowest-elevation site downstream at Riphug (Fig. 5). A Student's $t$ test showed a significant decrease in the amount of unreacted water between the July and September expeditions $(p<0.0005)$, likely a result of both an increasing proportion of glacier meltwater in the catchment and a transition towards the end of the monsoon.

Glacier outflow was parameterized as the $\delta^{18} \mathrm{O}$ of the outflow from Thanagang glacier; groundwater was parameterized using the $\delta^{18} \mathrm{O}$ value from the deep spring. Results show that, on average, $\sim 45 \%$ of river flow was glacier
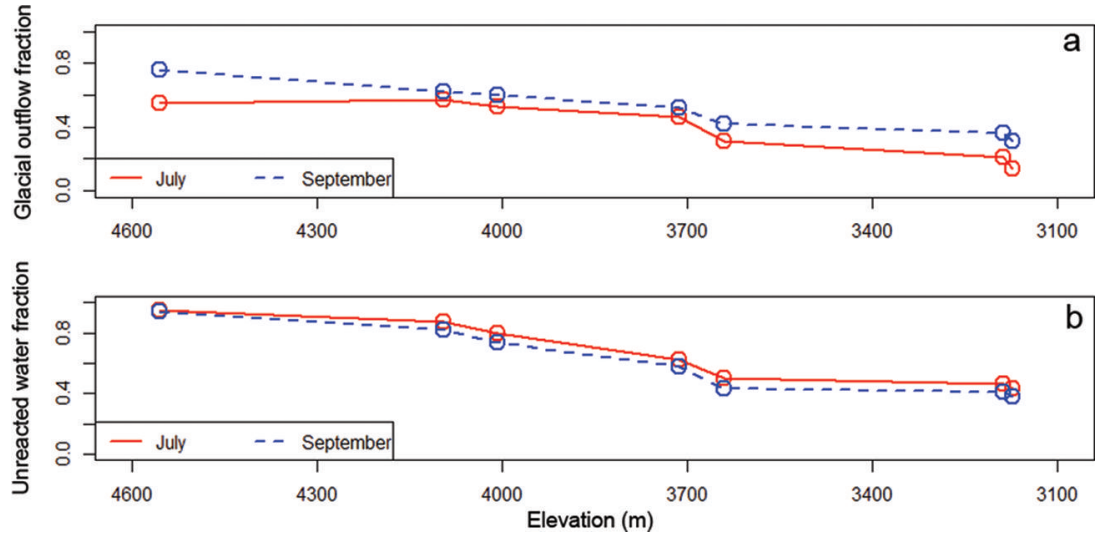

Fig. 5. Change in (a) glacial outflow fraction (calculated using $\delta^{18} \mathrm{O}$ ) and (b) unreacted water fraction (calculated using sulphate) of Chamkar Chhu streamflow with elevation. Remaining fractions are inferred to be groundwater (a) and reacted waters (b). 
outflow and $\sim 55 \%$ was groundwater. The contribution of flow from Thanagang glacier decreased with decreasing elevation, from $\sim 55 \%$ at the highest-elevation site to $<20 \%$ at the lowest-elevation site in July. By September, the contribution of glacier outflow ranged from $76 \%$ to $31 \%$ at the same sites. There was a significant increase in the contribution of glacial outflow to the Chamkar Chhu from July to September $(p<0.002)$. It is worth noting that the change in glacier contribution to streamflow for the Chamkar Chhu is similar to that reported by Racoviteanu and others (2013) for the Langtang river. The progressive depletion over the course of the season is thus interpreted to indicate an increase in glacier outflow contributions. It is also possible that monsoon rain isotopic values are influencing these trends; however, we do not have sufficient precipitation data to examine this possibility. The two-component hydrologic mixing model results indicate that within $25 \mathrm{~km}$ downstream the flow in the Chamkar Chhu changes from a mostly glacier output system to one dominated by groundwater. These results are consistent with the evaluation of glacierized Himalayan watersheds of Immerzeel and others (2013). They stated that, regardless of the role played by meltwater, rain runoff and base flow may also be important runoff components, especially when the timing is similar to that of the meltwater hydrograph.

\section{EMMA mixing model: source waters and flow paths}

The isotopic and geochemical information was combined using EMMA to further understand source waters and flow paths that contribute to water flow in the Chamkar Chhu. Conservative tracers were evaluated using the approach of Hooper (2003), and specifically an $R^{2}$ value $>0.88$ in plots of predicted versus measured values was found for all tracers, confirming that the projected values sufficiently capture the sample data. Thus seven tracers were used: $\mathrm{Na}^{+}$, $\mathrm{Mg}^{+}, \mathrm{K}^{+}, \mathrm{Ca}^{2+}, \mathrm{SO}_{4}{ }^{2-}, \mathrm{Cl}^{-}$and $\delta^{18} \mathrm{O}$. A PCA was performed to obtain eigenvalues and eigenvectors for the seven solutes selected. The river data were standardized and projected onto a U-space defined by the first three eigenvectors, along with all potential end members that were sampled (Fig. 6a and b), creating a three-component mixing model with four end members. The first PCA component explains $69 \%$ of the total variance in the Chamkar Chhu, the second PCA explains $13 \%$ and the third PCA explains $11 \%$. Based on the suggestion of Christophersen and Hooper (1992) and Liu and others (2004) that the chosen PCA components should explain $>90 \%$ of the variance, four end members are needed to explain $93 \%$ of the variance of the solute and isotopic content of the seven sites along the Chamkar Chhu (end members equal PCA components plus one).

Based on Figure $6 a$ and $b$, the four end members are snow (site 12), the shallow spring at Riphug (site 10), the deep spring at Tsampawog (site 9) and the tributary that flows into the Chamkar Chhu at Tsampa (site 6). Plotting the first and second principal components shows that samples plot higher on the PC2 axis in July, but in August and September the separation is less distinct (Fig. 6a). The gradient along the $\mathrm{PC} 1$ axis reflects elevational changes, as the samples on the left are from the highest-elevation sites and the samples that plot to the right are from the lowestelevation sites. On the PC1 axis, snow (site 12) is the only end member that bounds the higher-elevation sites on the left. The deep groundwater (site 9) and the Tsampa tributary (site 6) bound the samples to the right on the PC1 axis. The
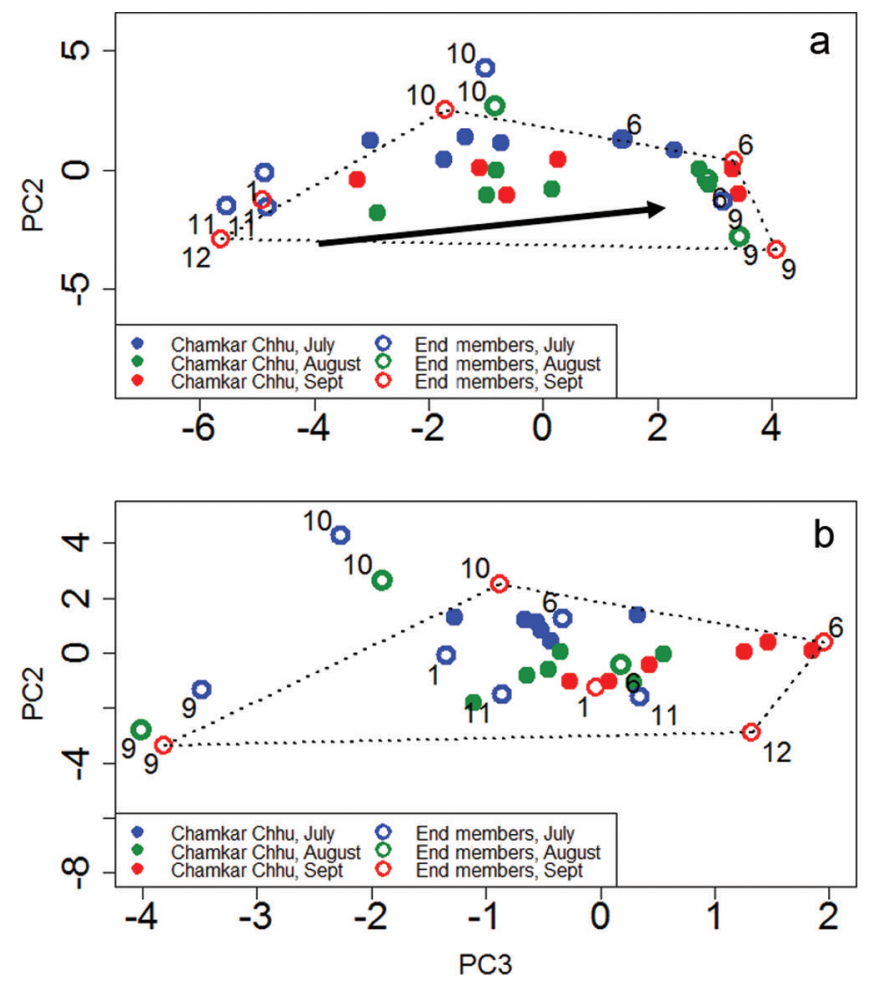

Fig. 6. Orthogonal projections of end members into U-space of (a) PC1 and PC2 and (b) PC2 and PC3. Principal components are derived from the isotopic and geochemical values of the Chamkar Chhu evaluated using PCA; solid symbols are different dates and sites from river samples. In (a) the trend with elevation in river samples is highlighted; the trend does not occur in (b). Dashed polygon connects September end members, which are numbered as in Table 1.

samples furthest to the right are the sites downstream of the Tsampa tributary, thus strongly controlled by the site 6 end member. On the PC2 axis, shallow groundwater and the tributary bound the samples on the upper end, and snow and deep groundwater bound the samples on the bottom, suggesting a transition from shallow groundwater to deeper groundwater over the 3 month sampling period.

On the plot of second and third principal components (Fig. 6b), the months are separated along PC3, but the elevation change is no longer distinct on either the PC2 or PC3 axis. The shift away from shallow groundwater (site 10) in July towards snow (site 12) in August and September shows a distinct change in the composition of streamflow as the monsoon progresses. The shift away from shallow groundwater over the course of the monsoon is consistent in both PCA plots. Snow, glacier ice (site 11) and glacier outflow (site 1) end members have similar chemistry and their spread on the PCA plots is driven by small differences in $\delta^{18} \mathrm{O}$, most notable on the PC3 axis. Glacier outflow and ice do not fit as well as snow when considering the end members along the PC3 axis. These results suggest that the left side of the PC1 axis is unreacted water (with snow, ice and glacial outflow all plotting close to each other), the right side of the PC1 axis is reacted water, PC2 is driven by differences in potassium, and PC3 is driven by differences in $\delta^{18} \mathrm{O}$.

A biplot enables visualization of both the observations and variables of multivariate data in the same plot, acting as a diagnostic tool with which to interpret the PCA results. In Figure 7 , the first two PCA axes account for $82 \%$ of the 


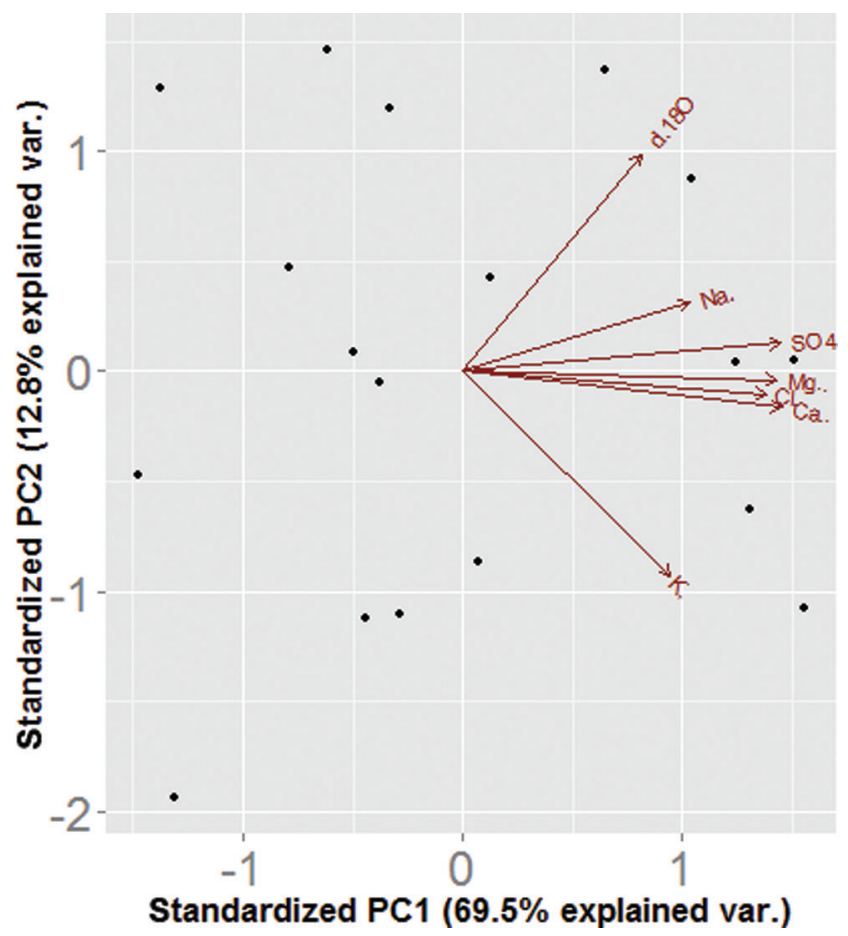

Fig. 7. Biplot of first and second principal components, where vectors represent conservative tracers and points are river sample numbers.

variance, which means that the biplot is a good approximation of the data. All the solutes consistent with a geochemical weathering source, except potassium, plot together on the first axis. In contrast, the $\delta^{18} \mathrm{O}$ values plot more towards the second axis, suggesting that $\delta^{18} \mathrm{O}$ values are in general independent of the geochemical weathering values. Potassium also plots more towards the second axis, but in the quadrant below $\delta^{18} \mathrm{O}$, meaning potassium is anti-correlated with $\delta^{18} \mathrm{O}$. Enriched potassium values were unique to the deep groundwater samples, suggesting that they are correlated with residence time, thus deeper and/or longer flow paths, and with geochemical weathering products at this site. Projections of the vectors onto the two standardized axes have magnitudes $<1$, implying that each principal component reduces the variance by only $\sim 40 \%$. These results are consistent with the need for a third PCA axis to explain some of the variance. Results from the biplot suggest that the first axis is heavily influenced by geochemical weathering, while the second axis, on which $\delta^{18} \mathrm{O}$ and potassium plot, is less dependent on geochemical weathering and more strongly influenced by the elevation and residence time factors that control $\delta^{18} \mathrm{O}$ and potassium content.

The EMMA solutions were evaluated by reproducing concentrations of all conservative tracers from the EMMA model and comparing them with measured values (Williams and others, 2006). In general, EMMA reproduced the measured concentrations well (Fig. 8). The difference of the means was $<16 \%$ for all conservative tracers, with the exception of chloride. Chloride had a difference of means of $0.7 \mu \mathrm{eq} \mathrm{L}^{-1}$, which equated to $21 \%$ due to the low concentrations of $<10 \mu \mathrm{eq} \mathrm{L}^{-1}$. These values are similar to those reported by Liu and others (2004) for a seasonally snowcovered catchment in the western USA. The correlations between measured and modeled concentrations were high for all tracers when using three eigenvectors for a fourcomponent mixing model, from an $R^{2}$ of 0.88 for chloride to 0.95 for calcium and $\delta^{18} \mathrm{O}$. These results suggest that EMMA was good at reproducing tracer values based on similar EMMA reconstructions by Liu and others (2004, 2008).

We then parameterized a four-component mixing model with the PCA values. The results show that in all three months snow comprised a significant portion of river flow at the highest sampling sites and decreased to nearly zero at the two lowest-elevation sites (Table 2). A major contributor to lower-elevation river water in all months was the Tsampa tributary. It contributed no water to discharge at the highestelevation site and comprised between $49 \%$ and $87 \%$ of flow

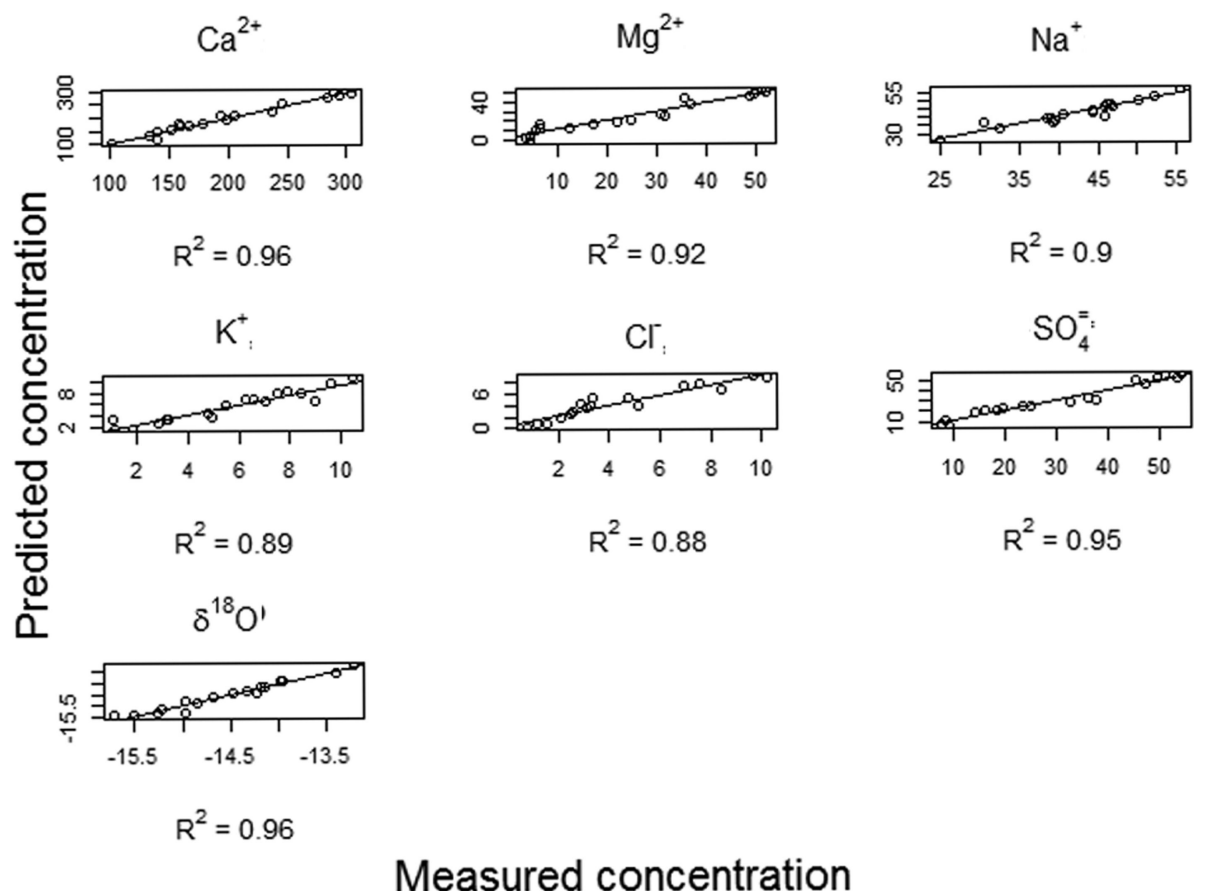

Fig. 8. Predicted versus measured concentrations for seven conservative tracers used in the Chamkar Chhu EMMA. 
Table 2. Contribution of the four end members to streamflow for the August expedition, calculated using a four-component hydrologic mixing model parameterized using EMMA and seven conservative tracers

\begin{tabular}{|c|c|c|c|c|c|c|c|c|c|c|c|c|}
\hline \multirow[t]{3}{*}{ Location } & \multicolumn{4}{|c|}{ July } & \multicolumn{4}{|c|}{ August } & \multicolumn{4}{|c|}{ September } \\
\hline & Snow & $\begin{array}{c}\text { Deep } \\
\text { ground- } \\
\text { water }\end{array}$ & $\begin{array}{l}\text { Shallow } \\
\text { ground- } \\
\text { water }\end{array}$ & $\begin{array}{l}\text { Tsampa } \\
\text { tributary }\end{array}$ & Snow & $\begin{array}{l}\text { Deep } \\
\text { ground- } \\
\text { water }\end{array}$ & $\begin{array}{c}\text { Shallow } \\
\text { ground- } \\
\text { water }\end{array}$ & $\begin{array}{l}\text { Tsampa } \\
\text { tributary }\end{array}$ & Snow & $\begin{array}{c}\text { Deep } \\
\text { ground- } \\
\text { water }\end{array}$ & $\begin{array}{c}\text { Shallow } \\
\text { ground- } \\
\text { water }\end{array}$ & $\begin{array}{l}\text { Tsampa } \\
\text { tributary }\end{array}$ \\
\hline & $\%$ & $\%$ & $\%$ & $\%$ & $\%$ & $\%$ & $\%$ & $\%$ & $\%$ & $\%$ & $\%$ & $\%$ \\
\hline Yarphu upstream & 24 & 10 & 58 & 7 & 35 & 15 & 19 & 27 & 33 & 0 & 18 & 50 \\
\hline Yarphu downstream & 15 & 0 & 61 & 24 & 28 & 5 & 33 & 34 & 35 & 19 & 20 & 26 \\
\hline Tsampa upstream & 9 & 10 & 66 & 15 & 22 & 29 & 28 & 21 & 20 & 0 & 22 & 58 \\
\hline Riphug upstream & 0 & 20 & 40 & 41 & 0 & 35 & 14 & 51 & 0 & 11 & 2 & 87 \\
\hline Riphug downstream & 0 & 21 & 59 & 20 & 0 & 27 & 24 & 49 & 1 & 38 & 2 & 60 \\
\hline
\end{tabular}

in August and September at the two lowest sites below the confluence of the tributary with the main stem of the Chamkar Chhu. In July at the two lower-elevation sites, groundwater comprised $60-80 \%$ of discharge. The two groundwater sites showed variable contributions to river flow that did not change consistently with elevation; however, by September the groundwater signal decreased and the Tsampa tributary dominated the two lowestelevation sites. Churugang, the highest-elevation site, had consistently high estimates of total groundwater contribution, likely influenced by high groundwater storage capacity in the unconsolidated sediments in the glaciated terrain of the upper basin.

One question that remains is whether these are the correct end members, or if one or more of the end members is a surrogate or proxy for another end member that was not measured. Monsoon rain was not measured and may be an important contributor to discharge, particularly at the lower sites. The shallow spring at Riphug, at relatively low elevation, had the most enriched $\delta^{18} \mathrm{O}$ values of any sample, and the $\delta^{18} \mathrm{O}$ values became more depleted from July to September. Additionally, this site always had relatively low solute content compared with the deep spring at site 9 and is interpreted as shallow groundwater. It is quite possible that the spring at Riphug represents 'new' water from monsoon rain (particularly in July) that has infiltrated the subsurface and picked up geochemical weathering products, similar to the 'new' water subsurface flow path suggested by Liu and others (2004) during snowmelt for a seasonally snow-covered catchment. The elevation of maximum monsoon precipitation is known to be $\sim 2500 \mathrm{~m}$ in the Langtang valley, Nepal (Baral and others, 2014). Above this elevation, precipitation decreases and becomes dominated by snow, decreasing the importance of monsoon rain as an end member as the glacier outflow is approached. It is also unclear whether the Tsampa tributary is a robust end member or a surrogate for another end member. The geochemical contribution of the tributary is certainly more enriched than the sites on the Chamkar Chhu above its confluence. The Tsampa tributary could represent a different groundwater source.

The high proportion (93\%) of variance explained by the three PCA components, along with the high $R^{2}$ of the correlation between modeled and measured tracer concentrations, suggests that the EMMA approach is robust with respect to the Chamkar Chhu watershed. It is clear that the contribution of groundwater - or reacted water - increases moving downstream in the Chamkar Chhu basin. Even if monsoon rain is important at lower elevations, it most likely infiltrates before contributing to streamflow, picking up geochemical contributions from ion exchange and bedrock weathering processes. While these results are encouraging, they strongly suggest that more potential end members, such as monsoon rain and additional springs, are sampled to better characterize groundwater variability.

\section{CONCLUSIONS}

As knowledge is sought about the impact of climate change on the mountains of Bhutan, the implications for downstream water resources are fundamental considerations. Snow- and ice melt provide a portion of the downstream water resources that agriculture and hydropower depend upon. While sparse data are a limiting factor in applying traditional hydrological models, the mixing models presented here using geochemical and isotopic tracers are a first step in evaluating relative contributions of glacial meltwater and groundwater to discharge in the Chamkar Chhu basin.

Two-component mixing models using $\delta^{18} \mathrm{O}$ to differentiate between groundwater and glacier outflow show that glacier outflow contributions increased from $\sim 55 \%$ of streamflow in July to $76 \%$ of streamflow in September at $4500 \mathrm{~m}$ near the terminus of Thanagang glacier. At the lowest-elevation site $(3100 \mathrm{~m})$, the glacier outflow contribution increased from $14 \%$ to $31 \%$ between July and September. A four-component EMMA shows glacier outflow contributions also increased as a proportion of discharge over the 3 month sampling period and decreased with distance downstream. The EMMA identified deep groundwater, shallow groundwater, snow, and a tributary with elevated chemical concentrations as the end members that best constrain the Chamkar Chhu dataset. Snow was geochemically and isotopically almost indistinguishable from glacier outflow and glacier ice samples, indicating that the 'snow' component of streamflow is driven by both ice melt and snowmelt. The absence of monsoon precipitation samples limits the interpretation of the EMMA; however, results from the different models indicate that a mixing model based on hydrochemistry can provide a quantitative evaluation of different source waters as contributors to streamflow in Bhutan if all potential end members are sampled. 


\section{ACKNOWLEDGEMENTS}

Primary support for this research came from the United States Agency for International Development (USAID) Cooperative Agreement AID-OAA-A-11-00045. Funding for M. Williams was provided in part by a US National Science Foundation grant to the Niwot Ridge Long-Term Ecological Research program. R. Kayastha was supported in part by a PEER award from USAID. A. Wilson was supported by a NASA Earth and Space Science Fellowship. We thank Sherubtse College in Bhutan for logistical support. This research could not have been conducted in this rugged and difficult terrain without the outstanding field staff of Dendup Tshering, Paljor Galey and Pema Lhendrup, and all lecturers at Sherubtse College.

\section{REFERENCES}

Bajracharya SR, Mool PK and Shrestha BR (2007) Impact of climate change on Himalayan glaciers and glacial lakes: case studies on GLOF and associated hazards in Nepal and Bhutan. International Centre for Integrated Mountain Development, Kathmandu

Baral P and 9 others (2014) Preliminary results of mass-balance observations of Yala Glacier and analysis of temperature and precipitation gradients in Langtang Valley, Nepal. Ann. Glaciol., 55(66), 9-14 (doi: 10.3189/2014AoG66A106)

Barthold FK, Tyralla C, Schneider K, Vache KB, Frede HG and Breuer L (2011) How many tracers do we need for end member mixing analysis (EMMA)? A sensitivity analysis. Water Resour. Res., 47(8) (doi: 10.1029/2011WR010604)

Christophersen N and Hooper RP (1992) Multivariate analysis of stream water chemical data: the use of principal components analysis for the end-member mixing problem. Water Resour. Res., 28(1), 99-107 (doi: 10.1029/91WR02518)

Christophersen N, Neal C, Hooper RP, Vogt RD and Andersen S (1990) Modelling streamwater chemistry as a mixture of soilwater end-members - a step towards second-generation acidification models. J. Hydrol., 116(1), 307-320 (doi: 10.1016/ 0022-1694(90)90130-P)

Craig H (1961) Isotopic variations in meteoric waters. Science, 133(3465), 1702-1703 (doi: 10.1126/science.133.3465.1702)

Drever JI (1997) Geochemistry of natural waters. Prentice-Hall, Upper Saddle River, NJ

Gardelle J, Berthier E, Arnaud Y and Kaab A (2013) Region-wide glacier mass balances over the Pamir-Karakoram-Himalaya during 1999-2011. Cryosphere, 7(6), 1885-1886 (doi: 10.5194/ tc-7-1885-2013)

Hooper RP (2003) Diagnostic tools for mixing models of stream water chemistry. Water Resour. Res., 39(3), 1055 (doi: 10.1029/ 2002WR001528)

Hooper RP and Shoemaker CA (1986) A comparison of chemical and isotopic hydrograph separation. Water Resour. Res., 22(10), 1444-1454 (doi: 10.1029/WR022i010p01444)

Immerzeel WW, Pellicciotti F and Bierkens MFP (2013) Rising river flows throughout the twenty-first century in two Himalayan glacierized watersheds. Nature Geosci., 6(9), 742-745 (doi: 10.1038/ngeo1896)

Kääb A, Berthier E, Nuth C, Gardelle J and Arnaud Y (2012) Contrasting patterns of early twenty-first-century glacier mass change in the Himalayas. Nature, 488(7412), 495-498 (doi: 10.1038/nature11324)

Karma, Ageta Y, Naito N, Iwata S and Yabuki H (2003) Glacier distribution in the Himalayas and glacier shrinkage from 1963 to 1993 in the Bhutan Himalayas. Bull. Glaciol. Res., 20, 29-40

Klaus J and McDonnell JJ (2013) Hydrograph separation using stable isotopes: review and evaluation. J. Hydrol., 505, 47-64 (doi: 10.1016/j.jhydrol.2013.09.006)

La Frenierre J and Mark BG (2014) A review of methods for estimating the contribution of glacial meltwater to total watershed discharge. Progr. Phys. Geogr., 38(2), 173-200 (doi: 10.1177/0309133313516161)
Land Use Planning Project Bhutan (1997) Atlas of Bhutan 1:250,000: land cover and area statistics of 20 dzongkhags. Ministry of Agriculture, Thimphu

Liu F, Williams MW and Caine N (2004) Source waters and flow paths in an alpine catchment, Colorado Front Range, United States. Water Resour. Res., 40, W09401 (doi: 10.1029/ 2004WR003076)

Liu F, Parmenter R, Brooks PD, Conklin MH and Bales RC (2008) Seasonal and interannual variation of streamflow pathways and biogeochemical implications in semi-arid, forested catchments in Valles Caldera, New Mexico. Ecohydrology, 1(3), 239-252 (doi: 10.1002/eco.22)

Lutz AF, Immerzeel WW, Shrestha AB and Bierkens MFP (2014) Consistent increase in High Asia's runoff due to increasing glacier melt and precipitation. Nature Climate Change, 4(7), 587-592 (doi: 10.1038/nclimate2237)

Meenawat $\mathrm{H}$ and Sovacool BK (2011) Improving adaptive capacity and resilience in Bhutan. Mitig. Adapt. Strategies Global Change, 16(5), 515-533 (doi: 10.1007/s11027-010-9277-3)

Murad AA and Krishnamurthy RV (2008) Factors controlling stable oxygen, hydrogen and carbon isotope ratios in regional groundwater of the eastern United Arab Emirates (UAE). Hydrol. Process., 22(12), 1922-1931 (doi: 10.1002/hyp.6776)

Naito $\mathrm{N}$ and 6 others (2012) Recent glacier shrinkages in the Lunana region, Bhutan Himalayas. Global Environ. Res., 16, 13-22

Nayar A (2009) When the ice melts. Nature, 461(7267), 1042-1046 (doi: 10.1038/4611042a)

Racoviteanu AE, Armstrong R and Williams MW (2013) Evaluation of an ice ablation model to estimate the contribution of melting glacier ice to annual discharge in the Nepal Himalaya. Water Resour. Res., 49(9), 5117-5133 (doi: 10.1002/wrcr.20370)

Rupper S, Schaefer JM, Burgener LK, Koenig LS, Tsering K and Cook ER (2012) Sensitivity and response of Bhutanese glaciers to atmospheric warming. Geophys. Res. Lett., 39, L19503 (doi: 10.1029/2012GL053010)

Schaner N, Voisin N, Nijssen B and Lettenmaier DP (2012) The contribution of glacier melt to streamflow. Environ. Res. Lett., 7(3), 034029 (doi: 10.1088/1748-9326/7/3/034029)

Sklash MG, Farvolden RN and Fritz P (1976) A conceptual model of watershed response to rainfall, developed through the use of oxygen-18 as a natural tracer. Can. J. Earth Sci., 13(2), 271-283 (doi: 10.1139/e76-029)

Suecker JK, Ryan JN, Kendall C and Jarrett RD (2000) Determination of hydrologic pathways during snowmelt for alpine/subalpine basins, Rocky Mountain National Park, Colorado. Water Resour. Res., 36(1), 63-75 (doi: 10.1029/1999WR900296)

Uhlenbrook S and Hoeg S (2003) Quantifying uncertainties in tracer-based hydrograph separations: a case study for two-, three-and five-component hydrograph separations in a mountainous catchment. Hydrol. Process., 17(2), 431-453 (doi: 10.1002/hyp.1134)

Wels C, Cornett RJ and Lazerte BD (1991a) Hydrograph separation: a comparison of geochemical and isotopic tracers. J. Hydrol., 122(1), 253-274 (doi: 10.1016/0022-1694(91)90181-G)

Wels C, Taylor CH, Cornett RJ and Lazerte BD (1991b) Streamflow generation in a headwater basin on the Precambrian Shield. Hydrol. Process., 5(2), 185-199 (doi: 10.1002/hyp. 3360050206)

Williams MW, Knauf M, Caine N, Liu F and Verplanck PL (2006) Geochemistry and source waters of rock glacier outflow, Colorado Front Range. Permafrost Periglac. Process., 17(1), 13-33 (10.1002/ppp.535)

Williams MW, Seibold C and Chowanski K (2009) Storage and release of solutes from a subalpine seasonal snowpack: soil and stream water response, Niwot Ridge, Colorado. Biogeochemistry, 95(1), 77-94 (doi: 10.1007/s10533-009-9288-x)

Wilson AM, Williams MW, Kayastha RB and Racoviteanu A (2016) Use of a hydrologic mixing model to examine the roles of meltwater, monsoon precipitation, and groundwater in the Langtang River Basin, Nepal. Ann. Glaciol., 57(71), 155-168 (doi: 10.3189/2016AoG71A067) 